\title{
MADURA FOOT
}

\section{A Study of Twenty Cases}

\author{
J. K. Oyston, Royal Air Force \\ From the Royal Air Force Hospital, Aden
}

This paper is based on a study of twenty consecutive cases of Madura foot treated in the Royal Air Force native hospital in Aden between December 1956 and August 1958. Madura foot or mycetoma pedis is a condition due to infection with fungal organisms belonging to the genera Nocardia or Madurella (Adams and Maegraith 1960). Nocardia is an aerobic actinomycete; Madurella is a true fungus. The picture of the disease described twenty years ago (Tribedi and Mukherjee 1939, Dixon 1941) is that of an emaciated patient with a foot grossly enlarged and pitted by numerous discharging sinuses (Fig. 1). The only effective treatment for such a patient is amputation, with all the disability implied by that procedure in a country where artificial limbs are not easily available and where little can be done to ensure employment for a cripple. However, only one of the patients in this series was of this very severe type; most of the others were seen when the disease was in an earlier stage and when there was an effective alternative to major amputation. The satisfactory results of treatment indicate the importance of early diagnosis.

\section{ANALYSIS OF MATERIAL}

Age and sex-The patients were often rather vague about their exact ages; most were young adults. There were four women and sixteen men (Table I). Few regularly wore shoes or sandals. History and clinical features-The patient usually complained of swelling of the foot. Pain was a feature in three, and discharge was the presenting symptom in three. The duration of symptoms was from one to 144 months (Table I), though the patients' vagueness about time made these figures rather speculative.

In eleven patients the left foot was affected; in eight the right. In one case the side involved was not recorded. Most commonly the forefoot was affected, and only in one case was the whole foot involved (Table I). There was involvement of regional lymph glands in one

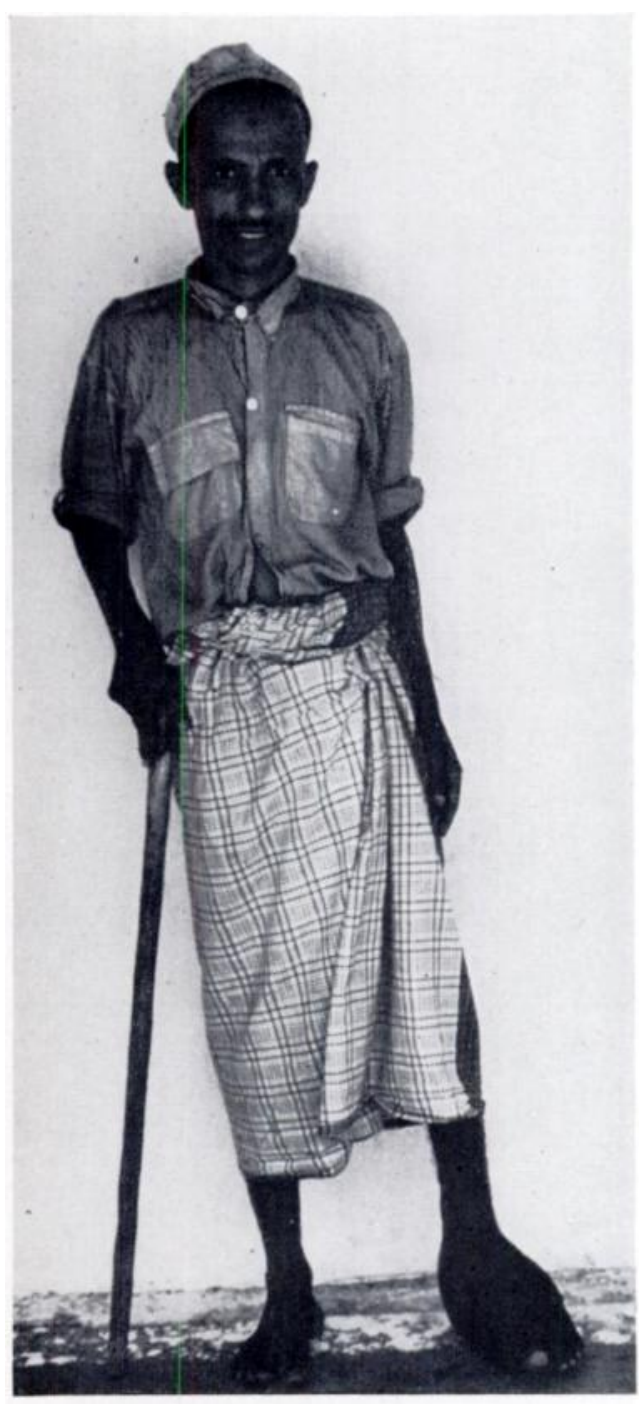

FIG. 1

A patient with advanced Madura foot (Case 1). Note the gross enlargement of the foot and evidence of constitutional disturbance. 
J. K. OYSTON

TABLE I

Analysis of Clinical Material

\begin{tabular}{|c|c|c|c|c|c|}
\hline $\begin{array}{c}\text { Case } \\
\text { number }\end{array}$ & Sex & History & $\begin{array}{c}\text { Duration of } \\
\text { symptoms } \\
\text { (months) }\end{array}$ & Site of lesion & $\begin{array}{l}\text { Radiological } \\
\text { findings }\end{array}$ \\
\hline 1 & Male & $\begin{array}{l}\text { Progressive nearly painless } \\
\text { swelling and sinuses }\end{array}$ & 12 & $\begin{array}{l}\text { Left foot and } \\
\text { inguinal glands }\end{array}$ & Gross bone destruction \\
\hline 2 & Male & Swelling & 2 & Right foot & $\begin{array}{l}\text { Periostitis in } \\
\text { calcaneo-cuboid region }\end{array}$ \\
\hline 3 & Female & - & - & Right foot & No abnormality \\
\hline 4 & Female & Swelling and ulceration & 3 & Right forefoot & No abnormality \\
\hline 5 & Male & Swelling and pain & 7 & $\begin{array}{l}\text { Lateral aspect of } \\
\text { right ankle }\end{array}$ & No bony abnormality \\
\hline 6 & Male & Pain and discharge & 8 & Left great toe & $\begin{array}{l}\text { Erosion of } \\
\text { proximal phalanx }\end{array}$ \\
\hline 7 & Male & Swelling & 3 & $\begin{array}{l}\text { Left first } \\
\text { intermetatarsal cleft }\end{array}$ & No abnormality \\
\hline 8 & Female & Swelling & 18 & Left foot & Not done \\
\hline 9 & Male & Swelling and aching & 6 & $\begin{array}{l}\text { Left foot below } \\
\text { medial malleolus }\end{array}$ & No abnormality \\
\hline 10 & Male & Swelling & 12 & $\begin{array}{l}\text { Left first } \\
\text { intermetatarsal cleft }\end{array}$ & No abnormality \\
\hline 11 & Male & Swelling & 9 & Dorsum of left foot & Not done \\
\hline 12 & Male & Swelling & 48 & Base of second left toe & Erosion of phalanx \\
\hline 13 & Male & Swelling & 5 & Sole of foot & No abnormality \\
\hline 14 & Male & $\begin{array}{l}\text { Swelling of foot } \\
\text { and pain in groin }\end{array}$ & 4 & Right foot & No abnormality \\
\hline 15 & Male & Swelling & 10 & Sole of right foot & Not done \\
\hline 16 & Male & Swelling and some pain & 144 & Left second toe & Not done \\
\hline 17 & Male & Swelling & 12 & Sole of left foot & Not done \\
\hline 18 & Female & Swelling & 8 & Right forefoot & No abnormality \\
\hline 19 & Male & Swelling & 一 & Right foot & Not done \\
\hline 20 & Male & Lump on foot & 1 & $\begin{array}{l}\text { Lateral aspect of } \\
\text { left tarsus }\end{array}$ & Not done \\
\hline
\end{tabular}

patient. In this case necrosis and discharge occurred and the fungus was recovered from the discharging gland. In one patient the regional lymph glands were simply enlarged in consequence of secondary infection of the primary lesion.

Appearance of primary lesion-Six patients showed ulceration or the typical sinuses with raised margins (Fig. 2). In one other case the swelling was topped by several hard nodules which seemed about to break down. The other patients showed swellings varying in shape and size and in degree of attachment to the surrounding tissue. Some were fluctuant and some seemed to be multilocular.

Radiological appearances-In eight cases the radiographs showed no abnormality of bone. In three the appearances were of superficial affection of bone and in one (Fig. 3) there was obvious evidence of extensive involvement. 
Systemic reaction-The lesion is essentially a local one and does not usually cause any constitutional disturbance. Only three patients were pyrexial and in all of these the pyrexia seemed to be due to secondary infection rather than to the disease itself. In none of the seven patients who had the investigation was there a leucocytosis.

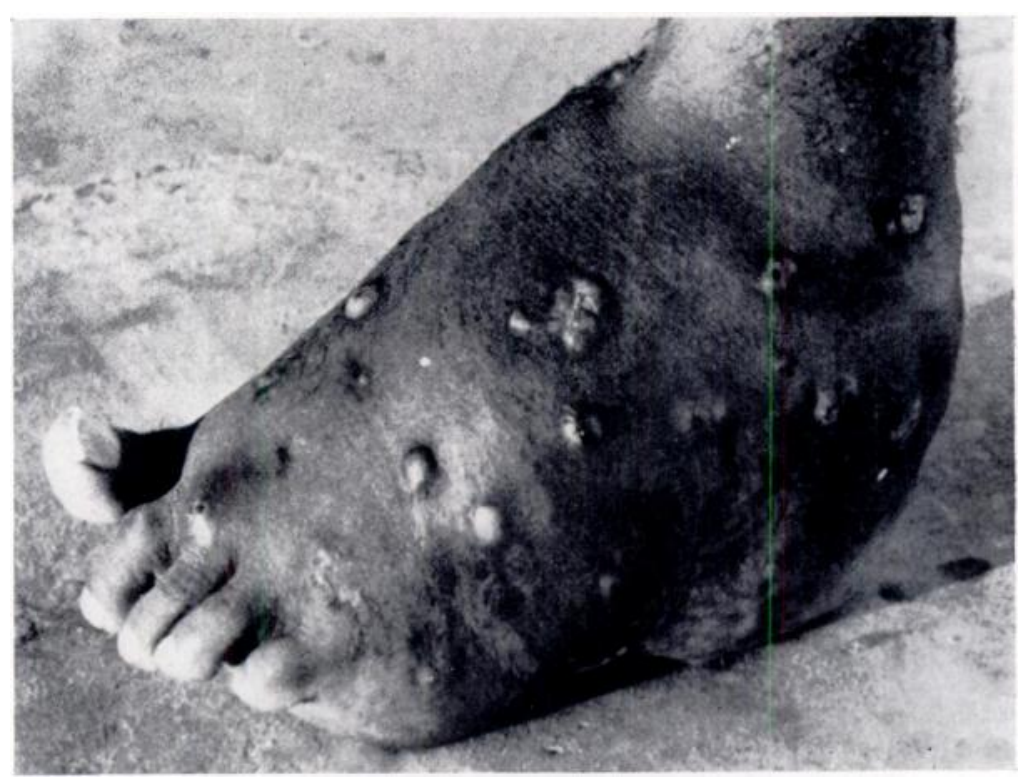

Fig. 2

Gross involvement of the whole foot showing the fusiform swelling and the sinuses with raised margins (Case 1).

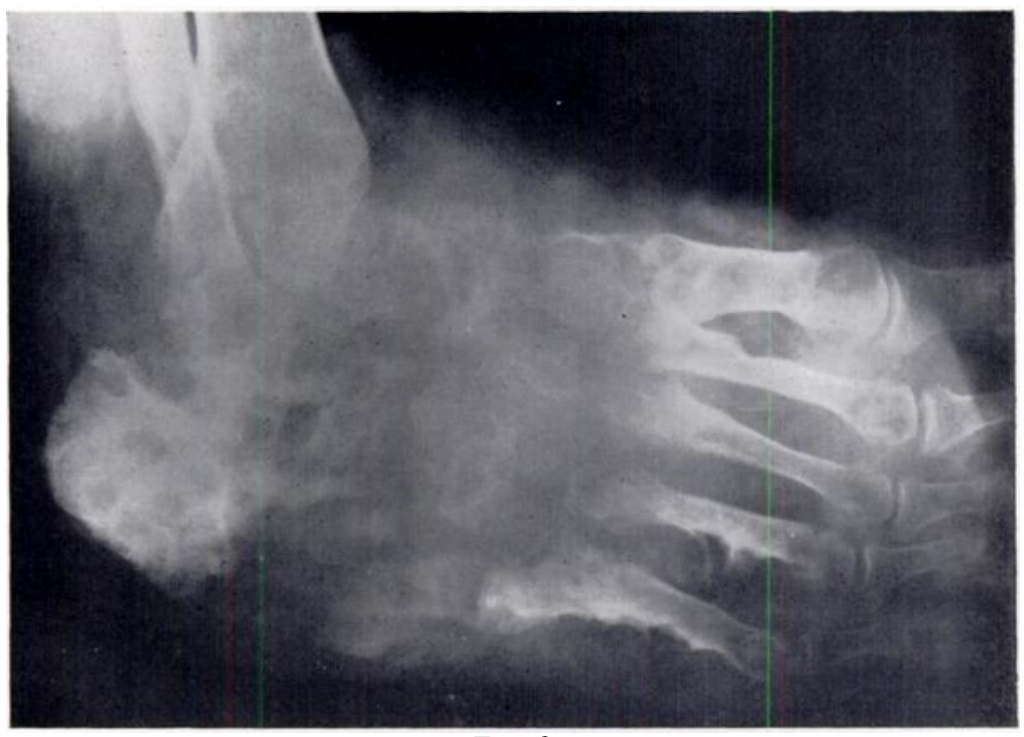

FIG. 3

Radiological appearances in a case of advanced infection. Note the gross destruction of bone and the swelling of soft tissues (Case 1).

Pathological features-The tissues involved were chiefly skin and subcutaneous tissue (eight patients) but in four muscle and tendon were affected, in three periosteum and in one bone. In four cases the tissue involved was not recorded. The recognition of the different types of causal organism (Erikson 1935, 1953, Mackinnon and Artagaveytia-Allende 1956) is a 


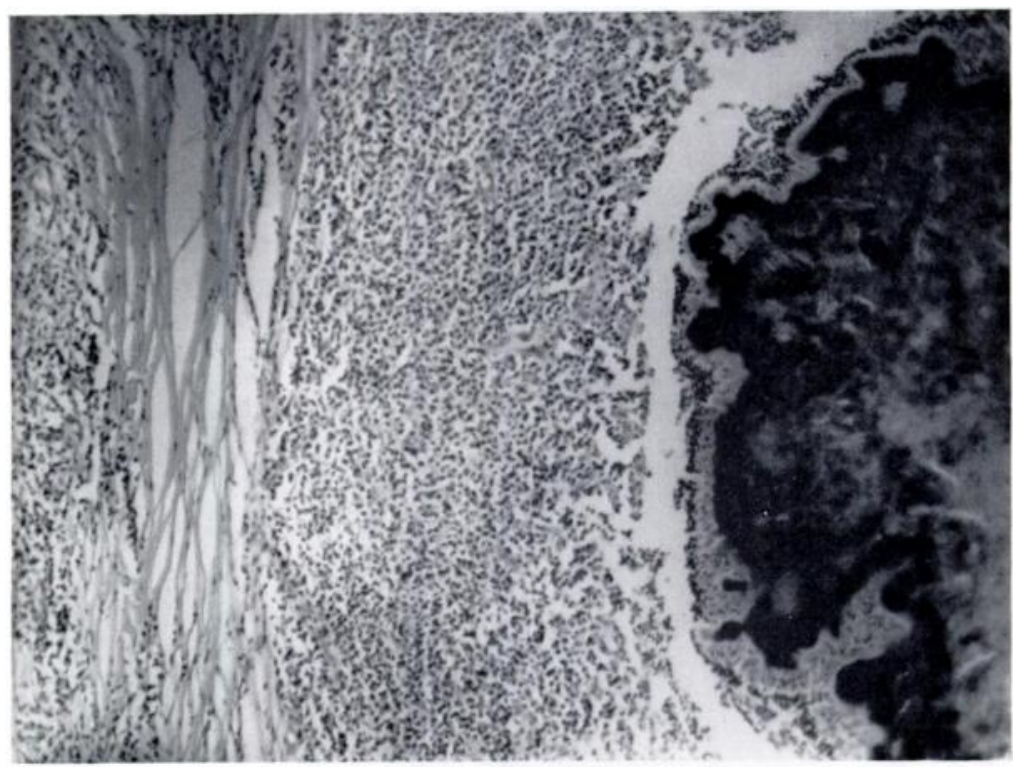

FIG. 4

Section through a lesion, showing the mycelial mass (on the right) surrounded by polymorphs, plasma cells and giant cells. The whole is surrounded by a fibrous "capsule" (on the left). ( 40.)

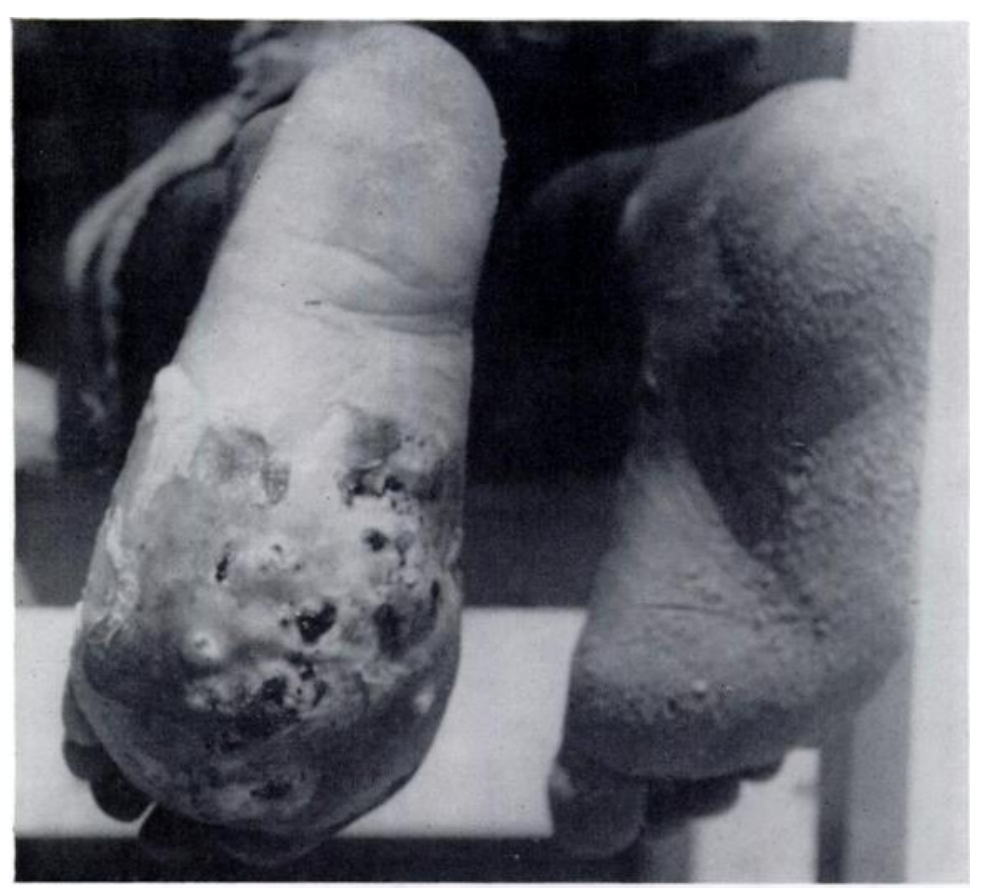

FIG. 5

Advanced mycetoma involving forefoot. Suitable for Syme's amputation. 
matter for an expert mycologist. The simplest classification-that depending on the colour of the granules present in the discharge-was accordingly used. The granules were black in three cases and yellow in nine. Their colour was not recorded in the other cases.

In the early stages there is an infected area of varying size and shape bounded by a fibrous capsule of varying thickness. This capsule may break down and further spread may thus occur. The lesion consists of aggregates of granules surrounded by inflammatory tissue. With breakdown of the capsule and involvement of other tissues the surrounding fibrous reaction becomes more intense.

Microscopically the lesion consists of a spherical collection of mycelium surrounded by cells of varying types. In some cases they are polymorphs, in others epithelioid cells. Plasma cells and giant cells may also be present. Surrounding the cells is an area of fibrous tissue (Fig. 4). In some cases there is a well marked palisade layer of eosinophil cells, adjacent to the mycelium.

\section{TREATMENT}

All the patients were treated with chlortetracycline 250 milligrams six hourly, combined with diaminodiphenylsulphone 50 milligrams daily for the first week, 100 milligrams daily for the second week and so on up to 250 milligrams daily. These drugs were not given over long periods because of doubts about their efficacy and because of the unwillingness of patients to stay long in hospital without marked evidence of improvement. They were used as adjuvants to operative treatment.

Operative treatment aimed at the removal of all infected tissues and closure of the ensuing wound. In some cases the disease area seemed to be encapsulated and could be shelled out; in others it had to be excised with a margin of healthy tissue. Amputation was only necessary when the affection was very extensive. After local excision primary closure was in one case possible: in eleven the area of skin excised was so large that the wound had to be left open to be covered later by a free graft. One patient was treated by excision of the lesion without primary closure or secondary grafting. Four patients with advanced disease had amputations; in two of them, with involvement of the forefoot only, Syme's method was used (Fig. 5). Three patients were treated by drugs alone, but unfortunately did not attend for review, and one left hospital after only a few days' treatment (Table II).

\section{RESULTS}

Unfortunately no adequate long term observation of these patients was possible because the patients simply failed to attend the follow-up clinic.

Medical treatment failed completely for similar reasons-in all three cases where it was attempted the patient either refused to stay in hospital or failed to attend the out-patient clinic.

Treatment by excision gave good results over the period during which observation was possible (Table II). In all eleven patients treated by local excision and later split-skin grafting the wounds were soundly healed at the time of discharge from hospital. The same satisfactory results followed the other methods of surgical treatment. One patient (Case 1) was kept under observation for twelve months; in this case there was advanced disease, but there was no evidence of recurrence during the period of observation.

\section{CASE REPORT}

This illustrates advanced disease of the classical type, but the case is not typical of those reported here.

A man aged about thirty years (Case 1) came to the clinic in September 1957 walking unshod with the aid of a stick. He complained of progressive swelling of the left foot over the past year and of a swelling in the left groin present for five months. There had been no pain.

VOL. 43 B, NO. 2, MAY 1961 
TABLE II

TREATMENT AND RESUlts

\begin{tabular}{|c|c|c|c|}
\hline $\begin{array}{c}\text { Case } \\
\text { number }\end{array}$ & Treatment & Result & $\begin{array}{c}\text { Time in } \\
\text { hospital } \\
\text { (days) }\end{array}$ \\
\hline 1 & Amputation and excision of glands & $\begin{array}{l}\text { Primary healing. } \\
\text { No recurrence ten months after discharge }\end{array}$ & 83 \\
\hline 2 & $\begin{array}{l}\text { Excision skin, muscle and periosteum. } \\
\text { Free graft seventeen days after excision }\end{array}$ & $\begin{array}{l}90 \text { per cent take of graft. } \\
\text { No recurrence at one month after discharge }\end{array}$ & 42 \\
\hline 3 & $\begin{array}{l}\text { Excision skin and subcutaneous tissues. } \\
\text { Free graft seven days after excision }\end{array}$ & 90 per cent take of graft & 61 \\
\hline 4 & Syme's amputation & Satisfactory stump & 51 \\
\hline 5 & Medical only & No improvement & 28 \\
\hline 6 & $\begin{array}{l}\text { Excision skin, subcutaneous tissue and } \\
\text { periosteum. Free graft sixteen days } \\
\text { after excision }\end{array}$ & Complete take of graft & 51 \\
\hline 7 & Excision skin and soft tissues & $\begin{array}{l}\text { Wound healed thirty days after excision. } \\
\text { No recurrence two months after discharge }\end{array}$ & 37 \\
\hline 8 & $\begin{array}{l}\text { Excision of skin and soft tissue. } \\
\text { Free graft twenty-one days after excision }\end{array}$ & Complete take of graft & 61 \\
\hline 9 & $\begin{array}{l}\text { Excision of skin and soft tissue. } \\
\text { Free graft eighteen days after excision }\end{array}$ & $\begin{array}{l}50 \text { per cent take of graft. } \\
\text { Healed thirty days after grafting }\end{array}$ & 57 \\
\hline 10 & $\begin{array}{l}\text { Excision of skin and soft tissue. } \\
\text { Free graft twelve days after excision }\end{array}$ & $\begin{array}{l}75 \text { per cent take of graft. } \\
\text { Healed nineteen days after grafting }\end{array}$ & 40 \\
\hline 11 & $\begin{array}{c}\text { Excision of skin and soft tissues. } \\
\text { Primary closure }\end{array}$ & Satisfactory healing & 20 \\
\hline 12 & $\begin{array}{l}\text { Disarticulation of toe. } \\
\text { Free graft fourteen days after amputation }\end{array}$ & Healed in fourteen days & 36 \\
\hline 13 & $\begin{array}{l}\text { Excision of skin and soft tissues. } \\
\text { Free graft twenty-eight days after excision }\end{array}$ & $\begin{array}{l}30 \text { per cent take of graft. } \\
\text { Healed fourteen days after grafting }\end{array}$ & 54 \\
\hline 14 & $\begin{array}{l}\text { Excision. } \\
\text { Free graft fourteen days after excision }\end{array}$ & 95 per cent take of graft & 31 \\
\hline 15 & Medical only & Left hospital refusing further treatment & 6 \\
\hline 16 & Medical only & Failed to attend for follow-up & 27 \\
\hline 17 & $\begin{array}{l}\text { Excision of skin and subcutaneous tissues. } \\
\text { Free graft seventeen days after excision }\end{array}$ & $\begin{array}{l}50 \text { per cent take of graft. } \\
\text { Wound healed twelve days after grafting }\end{array}$ & 33 \\
\hline 18 & Syme's amputation & Delayed healing. Final result satisfactory & 70 \\
\hline 19 & $\begin{array}{l}\text { Excision of skin, subcutaneous tissue and } \\
\text { muscle. } \\
\text { Free graft fourteen days after excision }\end{array}$ & $\begin{array}{l}\text { Complete take of graft } \\
\text { (length of stay because of } \\
\text { associated epididymitis) }\end{array}$ & 82 \\
\hline 20 & $\begin{array}{l}\text { Excision of skin and subcutaneous tissue. } \\
\text { Free graft fourteen days after excision }\end{array}$ & Good result & 38 \\
\hline
\end{tabular}

The patient was clearly in poor general health. Temperature and pulse were normal. The edge of his spleen was palpable two and a half inches below the left costal margin. The left foot was swollen to twice the size of the healthy one and was covered with sinuses with raised margins. The popliteal lymph glands were enlarged. There was an abscess in the left inguinal region with numerous sinuses and enlarged matted lymph glands (Fig. 6). Haemoglobin was 46 per cent; white blood cells were 5,000 per cubic millimetre-neutrophils 47 per cent, lymphocytes 51 per cent and eosinophils 2 per cent. 
Radiological appearances-There was advanced destruction of bone in the middle of the foot. In spite of this extensive destruction the bony arch was well preserved (Fig. 7). There was general decalcification of the forefoot with periostitis affecting particularly the fourth and fifth metatarsal bones. The calcaneum showed numerous spherical areas of decalcification surrounded by sclerosis.

Treatment-Chlortetracycline (250 milligrams six-hourly), diaminodiphenylsulphone (50 milligrams daily for one week, 100 milligrams daily for one week and 150 milligrams daily for one week) and potassium iodide (30 grains daily) were given, together with "Imferon" (250 milligrams on alternate days) and Folic acid ( 5 milligrams daily).

After three weeks' treatment the patient complained of pain in the foot and groin. The swellings had softened and white blood cells were 9,100 per cubic millimetre (neutrophils 86 per cent). There was still a marked anaemia. It was decided that operation was necessary.

Below-knee amputation with

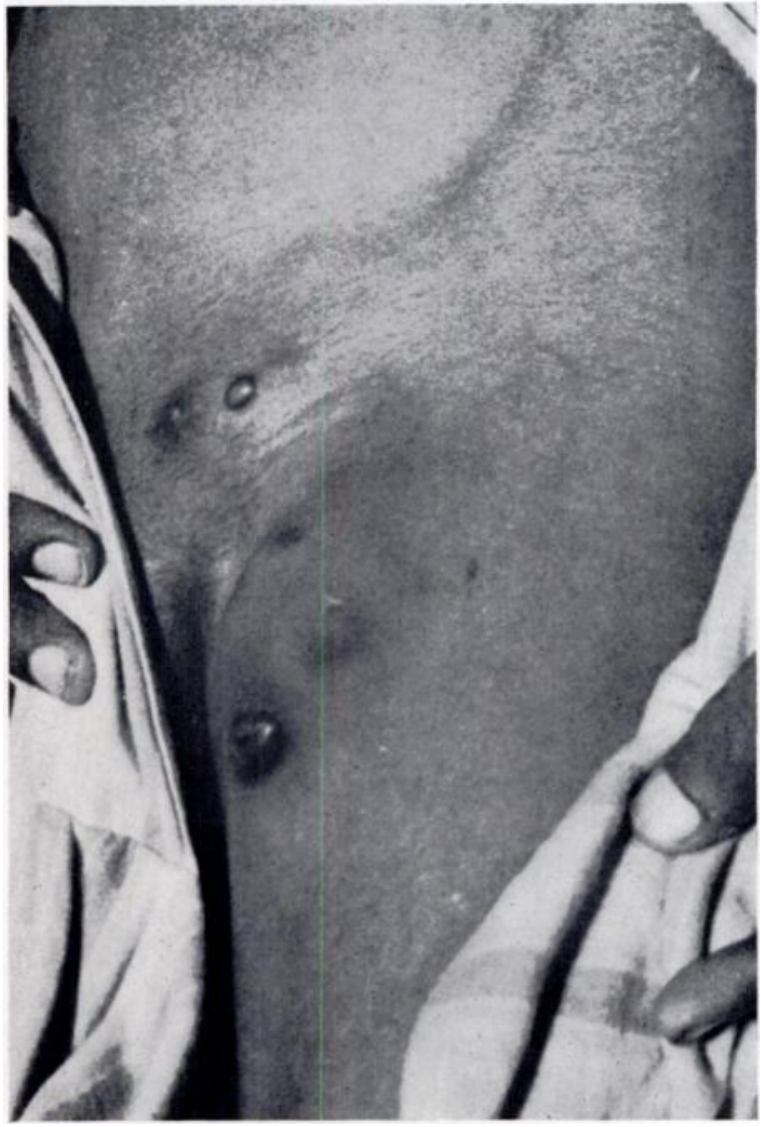

Fig. 6

Inguinal region showing enlarged lymph glands and sinuses (Case 1). primary closure over drainage tubes was done. Removal of the inguinal lymph glands was attempted but had to be abandoned before it was complete because of profuse bleeding and the patient's poor general condition. After transfusion of a pint of blood-all that could be obtained-and further treatment with iron the patient's condition gradually improved and his haemoglobin rose to 79 per cent. In November 1957 a second operation was done, the popliteal glands and the remaining inguinal glands being removed. All wounds healed primarily and the patient left hospital twelve weeks after admission. He was seen two months after discharge when there was no sign of recurrence, and ten months later was reported to be in good health.

Pathological examination-There was extensive involvement of the midtarsal region where the bone had been replaced by confluent spheres of dense fibrous tissue of an average diameter of 8 millimetres filled with caseous material off-white in colour. Islands of apparently unaffected bone were present in the forefoot and toes and the talus was only involved on its inferior surface. The calcaneum was pitted with small foci of caseation lacking a dense fibrous capsule (Fig. 8). The tibia seemed to be healthy.

On microscopy each lesion was seen to consist of a mycelial mass surrounded by polymorphs, epithelioid cells, plasma cells and giant cells. This was surrounded to a varying extent by fibrous tissue, this reaction being least marked in the early bony lesions.

The inguinal mass was formed by inflammatory cells surrounding mycelia.

VOL. 43 B, NO. 2, MAY 1961 


\section{DISCUSSION}

It is probable that the organisms, present in the soil, gain entry through cuts and abrasions in the unshod foot. The disease affects the active man in the place most often subjected to minor cuts and in contact with the soil. The forefoot is most often affected, possibly because

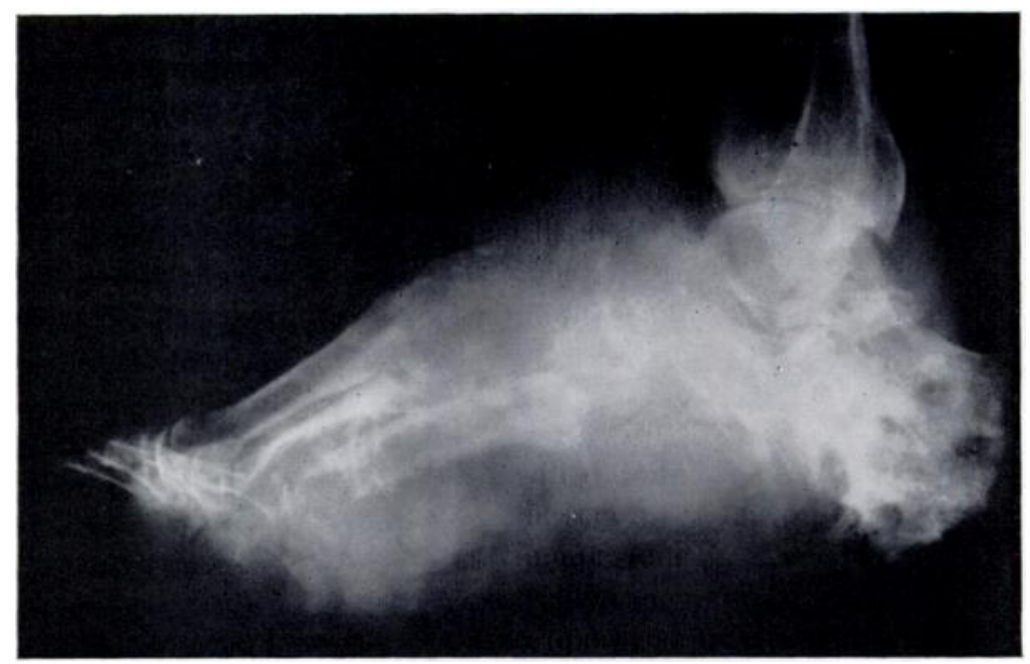

Fig. 7

Radiological appearances showing preservation of bony arch in spite of gross destruction of bone (Case 1).

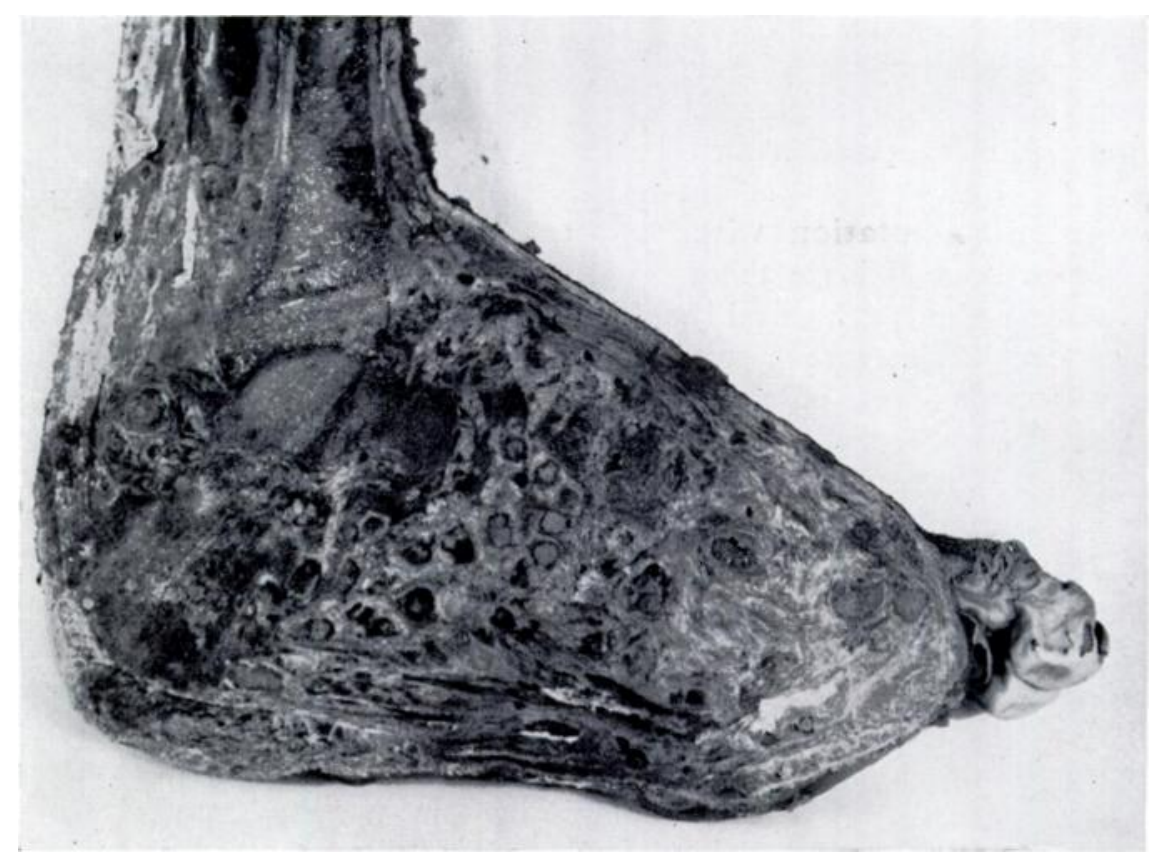

FIG. 8

Section through the amputated foot showing the extensive involvement and replacement of normal tissues by the mycetoma (Case 1).

it has areas of relatively soft skin between the hard weight-bearing areas. The incidence was related to occupation by Bocarro (1893) but more recently Peters (1945) showed that it depended more on whether the patient went barefoot. 
Most of the patients in this series had the disease recognised while it was in an early stage. The patient whose case is described had very advanced disease and-an unusual feature-infection of regional lymph glands by the fungus. This patient showed well-marked radiological changes.

The fungus seemed to grow more readily in subcutaneous and areolar tissues and only to invade deep structures late in the course of the disease. This finding is at variance with that of Dixon (1941) who described the lesion as burrowing indiscriminately through all tissues.

Surgical treatment by local excision was generally successful; there is no reliable evidence from this study of the value of chlortetracycline and diaminodiphenylsulphone. Treatment with sulphonamides (Dixon 1941, Peters 1945) was not tried.

\section{SUMMARY}

1. Twenty cases of mycetoma pedis are described.

2. Most patients had the disease in an early stage and were cured by simple excision.

3. The importance of early diagnosis and treatment in order to avoid amputation is emphasised.

I wish to thank the Director General Medical Services Royal Air Force for permission to publish this paper, and also Air Commodore L. M. Crooks, O.B.E., M.S., F.R.C.S., R.A.F. Consultant in Orthopaedic Surgery, for his advice and help.

\section{REFERENCES}

Adams, A. R. D., and Maegraith, B. G. (1960): Clinical Tropical Diseases. Second edition, p. 228. Oxford: Blackwell Scientific Publications.

Bocarro, J. E. (1893): An Analysis of One Hundred Cases of Mycetoma. Lancet, ii, 797.

Dixon, J. M. (1941): Sulfanilamide Therapy in Madura Foot. Virginia Medical Monthly, 68, 281.

ERIKson, D. (1935): The Pathogenic Aerobic Organisms of the Actinomyces Group. Medical Research Council Special Report Series No. 203. London: His Majesty's Stationery Office.

Erikson, D. (1953): Variation of Mycelial Pattern in Sporogenous and Asporogenous Actinomycetes. In Symposium on Actinomycetales, Sixth International Congress of Microbiology, p. 102. Rome: Fondazione Emanuele Paterno.

Mackinnon, J. E., and Artagaveytia-Allende, R. C. (1956): The Main Species of Pathogenic Aerobic Actinomycetes Causing Mycetomas. Transactions of the Royal Society of Tropical Medicine and Hygiene, 50, 31.

Peters, J. T. (1945): A Clinical Cure of Madura Foot. American Journal of Tropical Medicine, 25, 363.

Tribedi, B. P., and MukherjeE, B. N. (1939): Actinomycotic and Mycotic Lesions, with Special Reference to “Madura Foot." British Journal of Surgery, 27, 256. 